\title{
Temporal Distribution and Gas/Particle Partitioning of Polycyclic Aromatic Hydrocarbons (PAHs) in the Atmosphere of Strasbourg, France
}

\author{
Supansa Chimjarn ${ }^{1}\left(\mathbb{D}\right.$, Olivier Delhomme ${ }^{1,2}$ and Maurice Millet ${ }^{1, *}$ \\ 1 Centre National de la Recherche Scientifique, Institut de Chimie et Procédés pour l'Energie et la Santé, \\ Université de Strasbourg, (ICPEES UMR 7515), F-67000 Strasbourg, France; \\ supansa.chimjarn@gmail.com (S.C.); olivier.delhomme@univ-lorraine.fr (O.D.) \\ 2 Department of Science and Technology, Université de Lorraine, F-57070 Metz, France \\ * Correspondence: mmillet@unistra.fr; Tel.: +33-(0)368-852-866
}

Citation: Chimjarn, S.;

Delhomme, O.; Millet, M. Temporal Distribution and Gas/Particle Partitioning of Polycyclic Aromatic Hydrocarbons (PAHs) in the Atmosphere of Strasbourg, France. Atmosphere 2021, 12, 337. https:// doi.org/10.3390/atmos12030337

Academic Editor: Evangelos Tolis

Received: 10 February 2021

Accepted: 2 March 2021

Published: 5 March 2021

Publisher's Note: MDPI stays neutral with regard to jurisdictional claims in published maps and institutional affiliations.

Copyright: (c) 2021 by the authors. Licensee MDPI, Basel, Switzerland. This article is an open access article distributed under the terms and conditions of the Creative Commons Attribution (CC BY) license (https:// creativecommons.org/licenses/by/ $4.0 /)$.

\begin{abstract}
Gas and particulate phase ambient air concentrations of polycyclic aromatic hydrocarbons $\left(\Sigma_{16} \mathrm{PAHs}\right)$ were determined in Strasbourg, a large city located in the Alsace region of northeastern France, from May 2018 to March 2020, to study the evolution of their temporal variations and their potential origins. The analysis of PAHs was performed using a global analytical method permitting the quantification of pesticides, PAHs, and polychlorobiphenyls (PCBs). Filters and Carbon doped silicon carbide NMC@SiC foams were extracted by accelerated solvent extraction (ASE) followed by a solid-phase extraction (SPE). Afterwards, extracts were analyzed using gas chromatography coupled to tandem mass spectrometry (GC-MS/MS). Prior to analysis, a pre-concentration step based on solid-phase microextraction (SPME) was used with a polydimethylsiloxane (PDMS) $100 \mu \mathrm{m}$ fiber. The average total (gas plus particulate) concentration of $\Sigma_{16}$ PAHs varied from 0.51 to $117.31 \mathrm{ng} \mathrm{m}^{-3}$ with a mean of $16.87 \mathrm{ng} \mathrm{m}^{-3}$, with higher concentrations in the cold season of more than 2.5-fold and 6-fold that in the warm season for the gas and particulate phases, respectively. Moreover, low molecular weight (LMW) (2-ring and 3-ring) and medium molecular weight (MMW) (4-ring) PAHs contribute dominantly to the gas phase, while the particulate phase is associated with MMW (4-ring) and high molecular weight (HMW) (5-ring and 6-ring) PAHs. Gas/particle partitioning coefficient $(\log \mathrm{Kp})$ was calculated, and values varied between -4.13 and -1.49 . It can be seen that the $\log$ $\mathrm{Kp}$ increased with the molecular weight of the PAHs and that the log Kp is different between cold and warm seasons for HMW PAHs but not for LMW PAHs. Diagnostic ratios of PAHs, which were employed to estimate the primary source of PAHs in Strasbourg, indicate that fuel combustion and biomass/coal burning are the possible origins of PAHs in Strasbourg's atmosphere.
\end{abstract}

Keywords: PAHs; concentration distribution; diagnostic ratio; source apportionment

\section{Introduction}

Among the large number of atmospheric pollutants, polycyclic aromatic hydrocarbons (PAHs) are of great importance as these compounds, composed of two or more aromatic rings, are recognized as carcinogenic and mutagenic and consequently classified as priority pollutants by the American Environmental Protection Agency 'US EPA), the European Union, and the International Agency for Research on Cancer (IARC).

PAHs are ubiquitous contaminants and are derived mostly from anthropogenic origins of incomplete combustion, such as petrol and diesel engines, automobile exhaust, domestic heating, biomass burning, and various industrial activities. They can also originate from natural sources such as forest fires and volcanic eruptions [1]. Due to their relatively low vapor pressure, they can remain in the atmosphere for a long time and be transported over long distances [2,3]. Therefore, PAHs are considered long-range transport pollutants [4] and are found in all environmental compartments such as water, soils, vegetation, and 
dust $[5,6]$. In addition to their remanence in the environment, PAHs are important for their adverse toxicological [7-10] and ecotoxicological properties [11,12].

As PAHs are ubiquitous, toxic contaminants, they have been intensively monitored in the atmosphere [13-19]. One important source of PAH pollution in the urban atmosphere is caused by diesel and gasoline traffic emissions [20,21]. In large cities, traffic is generally heavy and congested and can generate significant emissions of PAHs. Some variations in emissions can occur according to the period of time, in particular when emissions from domestic heating are added to vehicle emissions in winter for example [13]. The importance of the different sources of PAHs in the urban atmosphere can be tentatively estimated by the calculation of the specific ratio of some particular PAHs [22]. It is thus valuable to determine the atmospheric levels and origins of PAHs in the urban atmosphere, since the risk of human exposure could be significant for the inhabitants.

This study presents the continuous monitoring (on a weekly basis) of PAHs in the background atmosphere of Strasbourg, a very polluted large city situated in the east of France, between May 2018 and March 2020, for the evaluation of the temporal variations of concentrations and their potential origins.

\section{Materials and Methods}

\subsection{Reagents and Chemicals}

Acetonitrile (ACN), ethyl acetate (EtAc), nitric acid, ethanol (EtOH), n-hexane (n-hex), methylene chloride (DCM), and toluene (TOL) of HPLC grade were purchased from VWR, France. Polydimethylsiloxane (PDMS) $100 \mu \mathrm{m}$ solid-phase microextraction (SPME) fibers and N-tert-butyldimethylsilyl-N-methyltrifluoroacetamide (MtBSTFA) were purchased from Sigma-Aldrich (St. Quentin Fallavier, France). Ultrapure water was obtained using an Elga system (VEOLIA, Antony, France). CHROMABOND ${ }^{\circledR}$ HLB solid-phase extraction (SPE) cartridges were purchased from Macherey-Nägel (Hoerth, France).

Mixtures of PAHs at $0.1 \mathrm{~g} \mathrm{~L}^{-1}$ in ACN were obtained from Cluzeau Info Labo (St Foy la Grande, France). Information on the PAHs used are shown in Supplementary Materials Table S1. A working mixture at $10 \mathrm{mg} \mathrm{L}^{-1}$ was prepared in ACN. These solutions were stored at $-18{ }^{\circ} \mathrm{C}$. Naphtalene- $\mathrm{d}_{8}$, phenanthrene- $\mathrm{d}_{10}$, chrysene- $\mathrm{d}_{12}$, and perylene- $\mathrm{d}_{12}$ at $0.01 \mathrm{~g} \mathrm{~L}^{-1}$ in ACN were used as internal standards (IS) and were obtained from SigmaAldrich (St. Quentin Fallavier, France).

\subsection{Sampling Site and Collection}

Samples were collected using a low-volume sampler $\left(2.3 \mathrm{~m}^{3} \mathrm{~h}^{-1}\right.$, Sven Leckel, Berlin, Germany) equipped with a $\mathrm{PM}_{10}$ head on a $47 \mathrm{~mm}$ glass fiber filter (WhatmanTM), followed by a silicon carbide foam coated with a thin layer of nitrogen-doped carbon (NMC@SiC). These foams were obtained from SICAT France [23].

Sampling was performed on a weekly basis between 15 May 2018 and 03 March 2020 in Strasbourg, a large city located in the Alsace region of northeastern France with the Vosges Mountains to the west and the Black Forest to the east. Strasbourg is an urban city containing shops, restaurants, residential areas, and the University of Strasbourg. Sampling was conducted on the roof of the University's Botanic Institute $\left(48.58 .40^{\circ}, 7.76 .63^{\circ}, 30 \mathrm{~m}\right.$ a.g.l.), which was situated approximately $3 \mathrm{~km}$ from major highways and industrial areas, $11 \mathrm{~km}$ from the regional airport, and $3.5 \mathrm{~km}$ from agricultural areas. The sampling site can be considered a typical background urbanized site. During the entire sampling period, it was not always possible to effect the weekly sample for organizational and maintenance reasons. The longest periods without realizing sampling were from 17 July 2018 to 4 September 2018, from 11 December 2018 to 19 February 2019, and from 23 July 2019 to 27 August 2019.

Prior to the sampling, filters and foams were subjected to cleaning by accelerated solvent extraction (ASE) using a mixture of n-hex/DCM (50:50, $v / v)$ followed by ACN at $1500 \mathrm{psi}$ for $45 \mathrm{~min}$. The ASE procedure applied consisted of three static cycles at $150^{\circ} \mathrm{C}$ for 15 min each. Afterwards, samplers were wrapped in aluminum foil and stored at $50^{\circ} \mathrm{C}$. 


\subsection{Extraction Sample Preparation of Filters and Foams}

The analysis of PAHs was performed using a global analytical method permitting the quantification of pesticides, PAHs, and polychlorobiphenyls (PCBs) [24]. In the following, the entire method procedure is described but only data for PAH quantification are detailed.

Filters and NMC@SiC foams were extracted by ASE twice using ACN at 1500 psi for $10 \mathrm{~min}$ at $150^{\circ} \mathrm{C}$. After extraction, MtBSTFA was added onto the ASE extract $(80 \mathrm{~mL})$ in order to derivatize some polar compounds (pesticides, phenols, and acids) for $1 \mathrm{~h}$ at $80^{\circ} \mathrm{C}$. After derivatization, these extracts $(80 \mathrm{~mL})$ were then diluted to $1000 \mathrm{~mL}$ with distilled water acidified by nitric acid $(\mathrm{pH}=3)$, followed by cleaning on CHROMABOND ${ }^{\circledR}$ HLB SPE cartridges using a DIONEX ${ }^{\circledR}$ AutoTrace 280 SPE system (Lévy et al. 2020).

The SPE procedure used was as follows: first the HLB adsorbents were conditioned with respectively $5 \mathrm{~mL}$ of $\mathrm{EtOH}$ and water, and then the ASE extracts $(1000 \mathrm{~mL})$ were loaded at $5 \mathrm{~mL} \mathrm{~min}^{-1}$ into the SPE cartridges. Afterwards, cartridges were dried under a nitrogen steam for $30 \mathrm{~min}$, and finally the analytes were consecutively eluted using $2 \mathrm{~mL}$ of each of the following solvents: DCM, EtAc, and ACN at $5 \mathrm{~mL} \mathrm{~min}{ }^{-1}$.

The collected extracts were gently concentrated to a droplet under a fume hood and finally dissolved in $1 \mathrm{~mL}$ of $\mathrm{ACN}$. Then, $100 \mu \mathrm{L}$ of the reconstituted extract was transferred into a vial for LC-MS/MS analysis, and $10 \mu \mathrm{L}$ of a $1 \mathrm{mg} \mathrm{L}^{-1}$ internal standard solution was added. The remaining $900 \mu \mathrm{L}$ was divided into four fractions of $225 \mu \mathrm{L}$. One of them was re-diluted to $20 \mathrm{~mL}$ using acidified and salted ( $\mathrm{pH} 3 ; 1.5 \% \mathrm{NaCl})$ distilled water, and $10 \mu \mathrm{L}$ of the appropriate IS $10 \mathrm{mg} \mathrm{L}^{-1}$ was added for GC-MS/MS analysis in order to promote their chromatographic analysis for pesticides including organochlorine pesticides (OCPs), PAHs, and polychlorobiphenyls (PCBs) as described in the method developed by Lévy et al. (2020).

\subsection{Analysis of PAHs in Sample Extracts}

The analysis of PAHs was performed on a TRACETM GC equipped with a split/splitless injector (splitless for $3 \mathrm{~min}$ ) and an Optima ${ }^{\circledR}$ XLB capillary column $(30 \mathrm{~m} \times 0.25 \mathrm{~mm}$, $0.25 \mu \mathrm{m})$, coupled to an ITQ ${ }^{\mathrm{TM}} 700$ ion trap mass spectrometer. Ionization was done in internal standard mode (EI mode). Details of the MRM method for PAHs are summarized in Supplementary Material Table S1. The injector, ion source, and transfer line were heated at $250{ }^{\circ} \mathrm{C}, 210{ }^{\circ} \mathrm{C}$, and $300^{\circ} \mathrm{C}$, respectively. The oven ramp was as follows: $50^{\circ} \mathrm{C}$ for $3 \mathrm{~min}$; followed by an increase in the temperature to $255{ }^{\circ} \mathrm{C}$ at $10{ }^{\circ} \mathrm{C} \mathrm{min}-1$ to finally increase to $330^{\circ} \mathrm{C}$ at $20^{\circ} \mathrm{C} \mathrm{min}-1$ where it was maintained for $18 \mathrm{~min}$. Helium with high purity $(\geq 99.999 \%)$ was used as the carrier gas at $1 \mathrm{~mL} \mathrm{~min}^{-1}$.

\subsection{SPME for GC-MS/MS Analysis}

Prior to GC-MS /MS analysis, the obtained $20 \mathrm{~mL}$ acidified extracts were re-concentrated by SPME using a CTC CombiPAL autosampler. PAHs were extracted at $80^{\circ} \mathrm{C}$ for $40 \mathrm{~min}$ using a polydimethylsiloxane (PDMS) $100 \mu \mathrm{m}$ fiber.

\section{6. $Q A / Q C$}

Two blank series were prepared; the first consisted of pre-cleaned samplers extracted and analyzed, while the second consisted of a field blank sampler extracted and analyzed. These later were packed pre-cleaned after field exposition for the same duration as field samplers. None of the assessed molecules were detected in the analyzed blank samplers, which confirms the efficiency of the cleaning and storage procedures used.

SPE was done in triplicate for each of the assessed compounds in order to calculate an average recovery rate $(\%)$.

Matrix matched calibration curves were dressed by spiking NMC@SiC foam with 1 , $10,25,50,100,250,500$, and 1000 ng of pollutants. All curves were dressed in triplicate. These calibration curves were used for PAH quantification in filters as it was not possible to spike filters with standardized particles containing PAHs. 
Repeatability was tested by spiking on the same day, using 5 NMC@SiC foams with 3 levels of concentration 10, 100, and $1000 \mathrm{ng}$ of pollutants. In fact, spiked foams were extracted and prepared at the same time and analyzed on the same day. This experiment was repeated for three successive weeks. It should be noted that the intra-day precision (repeatability) of the assay was estimated by calculating the relative standard deviation (RSD) for the analysis of QC samples in 3 replicates, while the inter-day precision (reproducibility) was determined by the analysis of the replicate QC samples on three consecutive weeks. All extraction and concentration steps were done in triplicate, and recoveries were between $65 \%$ and $98 \%$ for the assessed congeners, which agrees with the US EPA 1668a norm.

Limits of detection (LOD) and quantification (LOQ) were calculated based on a signal to noise ratio of 3:1 and 10:1 basis, respectively, following these equations:

$$
\begin{gathered}
-\mathrm{LOD}=3 \times[\mathrm{Cmin}] /(\mathrm{S} / \mathrm{N}) \\
\mathrm{LOQ}=10 \times[\mathrm{Cmin}] /(\mathrm{S} / \mathrm{N})
\end{gathered}
$$

where $[\mathrm{Cmin}]=$ minimal concentration, $\mathrm{S}=$ signal detected at this concentration, and $\mathrm{N}=$ noise. Moreover, uncertainties on each congener were calculated and shown to be in the range of 3-20\%. Limits of detection and quantification are summarized in Supplementary Material Table S1.

\subsection{G/P Partitioning}

Gas-particle distribution coefficient $\mathrm{Kp}\left(\mathrm{m}^{3} \mu \mathrm{g}^{-1}\right)$ was calculated for PAHs using the following formula (Equation (1)) proposed by Yamasaki et al. (1982) [25]:

$$
\mathrm{Kp}=(\mathrm{Cp} / \mathrm{TSP}) / \mathrm{Cg}
$$

where TSP is the concentration of total suspended particulate matter $\left(\mu \mathrm{g} \mathrm{m}^{-3}\right)$, and Cp and $\mathrm{Cg}$ are the compound concentrations in the particulate and in the gas phase, respectively. TSP values were obtained from the Atmospheric Pollution Survey network ("Atmo Grand-Est").

\section{Results}

\subsection{Annual Concentration and Seasonal Variability of PAHs}

PAHs were determined from May 2018 to March 2020 in the air of the Strasbourg area. The mean concentration of each PAH is presented in Table 1. The average total concentration of $\Sigma_{16} \mathrm{PAHs}$ in the air (gas and particulate phases) was $16.87 \mathrm{ng} \mathrm{m}^{-3}$ (min: $0.51 \mathrm{ng} \mathrm{m}^{-3}$ and max: $117.31 \mathrm{ng} \mathrm{m}^{-3}$ ).

The mean concentration obtained was comparable to that measured in the urban area of Marseille (21.79 $\mathrm{ng} \mathrm{m}^{-3}$ ), the largest city in the South of France [26], and in the urban area of Grenoble $\left(\Sigma_{16}\right.$ PAHs $\left.23.11 \mathrm{ng} \mathrm{m}^{-3}\right)$, France [27]. However, this mean PAH concentration was not in the same degree as the study by Morville et al. (2011) [13] relative to atmospheric gas and particulate phases collected from 2002 to 2004 at the same site in Strasbourg. These authors found a mean concentration of $\Sigma_{17} \mathrm{PAHs}$ of $149 \mathrm{ng} \mathrm{m}^{-3}$, which is more than 8 times higher than the concentration found in this study $\left(16.87 \mathrm{ng} \mathrm{m}^{-3}\right)$. This very different value is caused by the higher concentrations of low molecular weight PAHs $(\mathrm{MW}<202)$ as NAP $\left(43.9>4.27 \mathrm{ng} \mathrm{m}^{-3}\right)$, PHE $\left(24.5>1.72 \mathrm{ng} \mathrm{m}^{-3}\right)$, ACE $\left(20.3>0.66 \mathrm{ng} \mathrm{m}^{-3}\right)$, FLU $\left(9.7>0.52 \mathrm{ng} \mathrm{m}^{-3}\right)$, FLA $\left(9.1>1.24 \mathrm{ng} \mathrm{m}^{-3}\right)$, ANT $\left(2.3>0.40 \mathrm{ng} \mathrm{m}^{-3}\right)$, and PYR $\left(4.8>0.40 \mathrm{ng} \mathrm{m}^{-3}\right)$, while the concentrations of HMW PAHs obtained by the two studies were not significantly different. The difference in the profile of LMW PAH distribution at the Strasbourg site between the two studies can probably be explained by the different types of active samplers used, with different duration and time. More precisely, in the previous report by Morville et al. (2011), a high-volume sampler performed for $4 \mathrm{~h}$ with three time intervals per day (time interval of high vehicle traffic) for a few days a month in each season was used, while this study used a low-volume sampler performed on a weekly 
basis throughout the year. The age of the data in the previous study (from 2002 to 2004) and the period to which they relate are also important factors to explain the difference with our recent work.

Table 1. Annual mean concentrations of individual polycyclic aromatic hydrocarbons (PAHs) quantified in gas and particulate phases.

\begin{tabular}{|c|c|c|c|c|c|}
\hline & \multicolumn{2}{|c|}{ n $(\%)$} & \multicolumn{3}{|c|}{ Annual Average Concentration (min-max) } \\
\hline & Gas & Particle & Gas $\left(\mathrm{ng} \mathrm{m}^{-3}\right)$ & Particle (ng m ${ }^{-3}$ ) & $\Sigma G+P\left(\right.$ n m $\left.^{-3}\right)$ \\
\hline Naphtalene (NAP) & 96 & 48 & $4.20(0.005-25.87)$ & $0.05(0.001-0.78)$ & $4.25(0.005-25.90)$ \\
\hline Acenaphtene (ACE) & 97 & 57 & $0.63(0.030-2.56)$ & $0.03(0.001-1.89)$ & $0.66(0.03-2.56)$ \\
\hline Fluorene (FLU) & 98 & 84 & $0.51(0.003-2.33)$ & $0.01(0.001-0.08)$ & $0.52(0.04-2.33)$ \\
\hline Phenanthrene (PHE) & 100 & 100 & $1.66(0.003-19.05)$ & $0.06(0.005-0.23)$ & $1.72(0.005-19.20)$ \\
\hline Anthracene (ACE) & 74 & 48 & $0.33(0.003-6.20)$ & $0.07(0.001-0.91)$ & $0.40(0.003-6.20)$ \\
\hline Fluoranthrene (FLA) & 97 & 91 & $0.82(0.002-11.55)$ & $0.42(0.024-1.83)$ & $1.24(0.002-11.98)$ \\
\hline Pyrene (PYR) & 97 & 93 & $0.66(0.004-13.28)$ & $0.23(0.005-2.06)$ & $0.89(0.05-13.65)$ \\
\hline Benz(a)anthracene (BaA) & 97 & 100 & $0.77(0.004-7.53)$ & $0.65(0.014-2.44)$ & $1.42(0.035-8.79)$ \\
\hline Chrysene (CHR) & 97 & 100 & $0.33(0.002-3.21)$ & $0.28(0.006-1.04)$ & $0.61(0.015-3.54)$ \\
\hline Benzo(b)/(k)fluoranthrene (BaF/BkF) & 81 & 97 & $0.27(0.004-2.87)$ & $0.30(0.022-1.81)$ & $0.57(0.004-3.44)$ \\
\hline Benzo(e)pyrene $(\mathrm{BeP})$ & 86 & 98 & $0.23(0.002-2.94)$ & $0.21(0.008-1.57)$ & $0.44(0.008-3.46)$ \\
\hline Benzo(a)pyrene (BaP) & 88 & 100 & $0.14(0.002-1.68)$ & $0.35(0.004-3.99)$ & $0.49(0.006-5.53)$ \\
\hline Dibenz(a.h)anthracene (DBahA) & 38 & 67 & $0.25(0.02-0.57)$ & $0.66(0.08-2.16)$ & $0.91(0.08-2.20)$ \\
\hline Indenol(1,2,3)pyrene (IndP) & 33 & 40 & $0.29(0.03-0.87)$ & $1.04(0.125-3.73)$ & $1.33(0.13-3.73)$ \\
\hline Benzo(g,h,i)perylene (BghiP) & 45 & 72 & $0.27(0.057-0.84)$ & $1.15(0.094-4.38)$ & $1.42(0.094-5.19)$ \\
\hline$\Sigma_{16}$ PAH & & & $11.36(0.174-101.35)$ & $5.51(0.391-28.90)$ & $16.87(0.51-117.70)$ \\
\hline
\end{tabular}

$n$ : percentage of positive samples detected in the gas and particulate phases.

The annual trends of $\Sigma_{16} \mathrm{PAH}$ concentrations in both gas and particulate phases with temperature are presented in Figure 1.

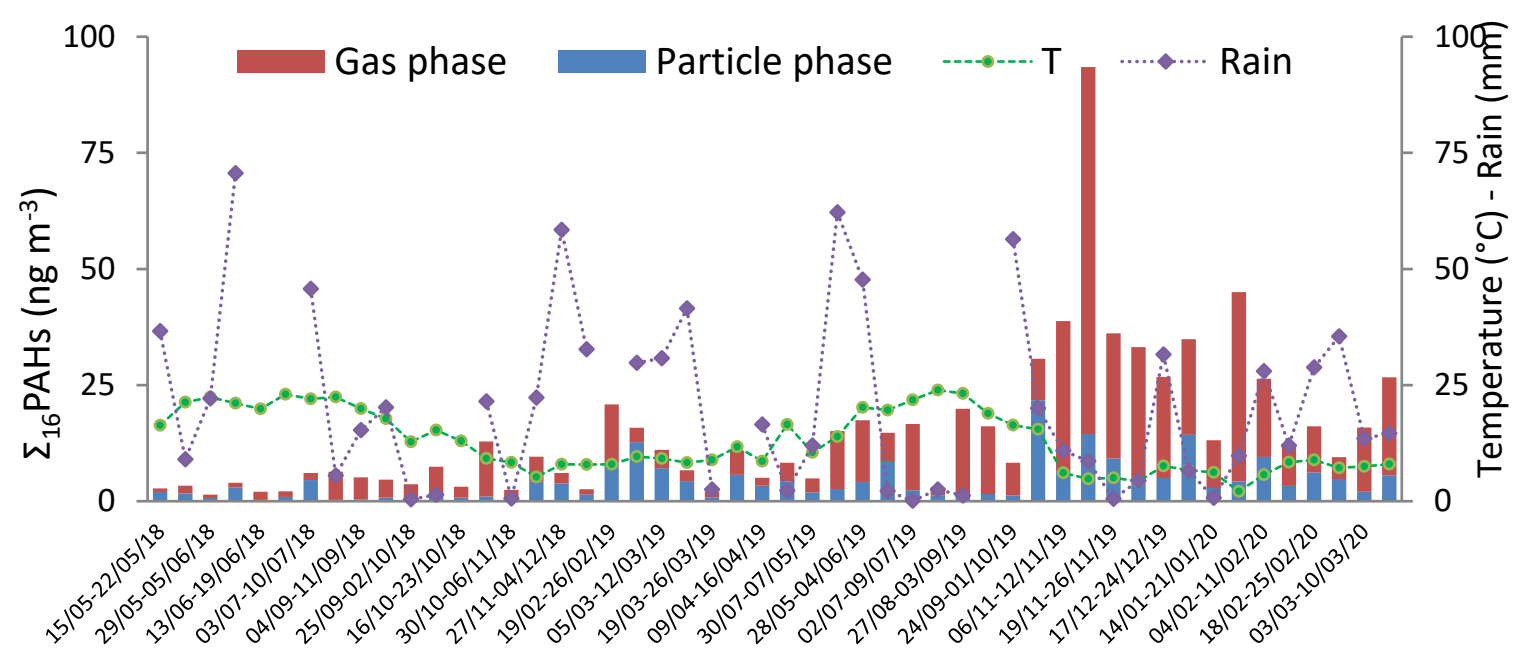

Figure 1. Annual variations of gas and particulate phase PAH concentrations and temperatures from 15 May 2018 to 17 March 2020.

For gas phase samples, the mean concentration of $\Sigma_{16} \mathrm{PAHs}$ was $11.36 \mathrm{ng} \mathrm{m}^{-3}$, with a maximum of $79 \mathrm{ng} \mathrm{m}^{-3}$ on 12 to 19 November 2019 , with a temperature of $4.8 \pm 0.91{ }^{\circ} \mathrm{C}$, and a minimum of $0.74 \mathrm{ng} \mathrm{m}^{-3}$ on 29 May to 5 June 2018 , with a temperature of $22.4 \pm 1.46^{\circ} \mathrm{C}$. The PAH concentration in the particulate phase was considerably lower, with a mean value of $5.51 \mathrm{ng} \mathrm{m}^{-3}$, and ranged from 0.29 to $21.73 \mathrm{ng} \mathrm{m}^{-3}$.

Additionally, the average concentrations of $\Sigma_{16} \mathrm{PAHs}$ in gas and particulate phases during each season in 2018 and 2019 with the temperature and concentration of total suspended particles (TSP) are presented in Figure 2. 


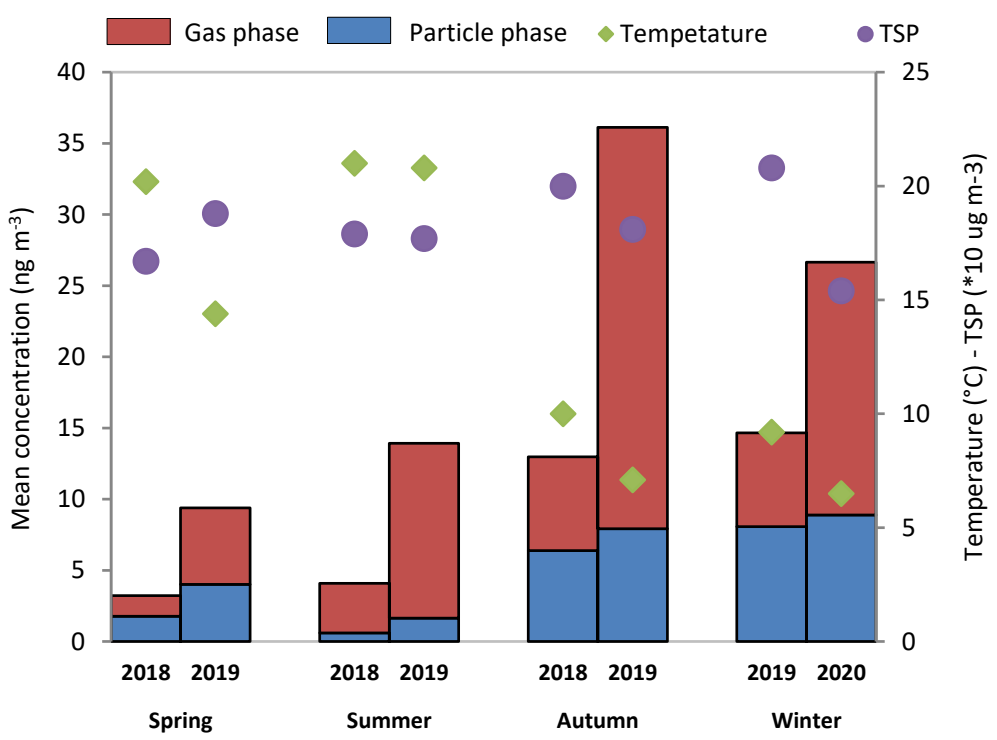

Figure 2. Average concentrations of $\Sigma_{16} \mathrm{PAHs}$ in the particulate and gas phases for four seasons with temperature and total suspended particles (TSP).

The seasonal variability of PAHs shows higher concentrations in autumn and winter and lower concentrations in spring and summer. For the gas phase, the maximum concentration was observed in spring, and it decreased slightly in winter with lower temperature, while the minimum concentration was in spring, and it got slightly higher in summer with higher temperature (warm and non-heating season). Moreover, a strong variation can be observed between 2018 and 2019 in the gas phase; this observation can be probably explained by lower temperature in 2019 than 2018, except in the summer period (average temperature of $21.2{ }^{\circ} \mathrm{C}$ in 2018 and $20.8^{\circ} \mathrm{C}$ in 2019). Indeed, the average temperature values are $20.2^{\circ} \mathrm{C}$ in 2018 and $14.4^{\circ} \mathrm{C}$ in 2019 during the spring period, $10.1^{\circ} \mathrm{C}$ in 2018 and $7.1^{\circ} \mathrm{C}$ in 2019 during the autumn period, and $9.2^{\circ} \mathrm{C}$ in 2018 and $6.5^{\circ} \mathrm{C}$ in 2019 during the winter period (Figure 2). For the particulate phase, the PAH concentrations have a similar trend to the study by Delhomme et al. (2012) [14], which reported PAH concentrations in $\mathrm{PM}_{10}$ during each season.

The $\Sigma_{16} \mathrm{PAH}$ concentrations in the particulate phase have a minimum in summer and increase from spring to winter, and in 2018 and 2019, a small variation between both years was found. The light difference in concentrations for the particulate phase in both years is probably due to the slightly different concentrations of TSP in the air. From the literature, the temperature and meteorological conditions are important factors influencing the distribution of PAHs for seasonal behavior of PAHs in the atmosphere [28,29]. A lower $\mathrm{PAH}$ concentration in the warm season and a higher concentration in the cold season were reported in numerous studies [30-32]. Besides the meteorological factors, the emission source of PAHs is the main factor for seasonal variations [33]. In this study, the PAH concentration in the cold season was approximately 2.5 -fold and 6-fold more than that in the warm season for the gas and particulate phases, respectively.

\subsection{Gas-Particle Partitioning}

The profiles of relative distribution of PAHs by number of rings for four seasons in Strasbourg were studied (Figure 3). 

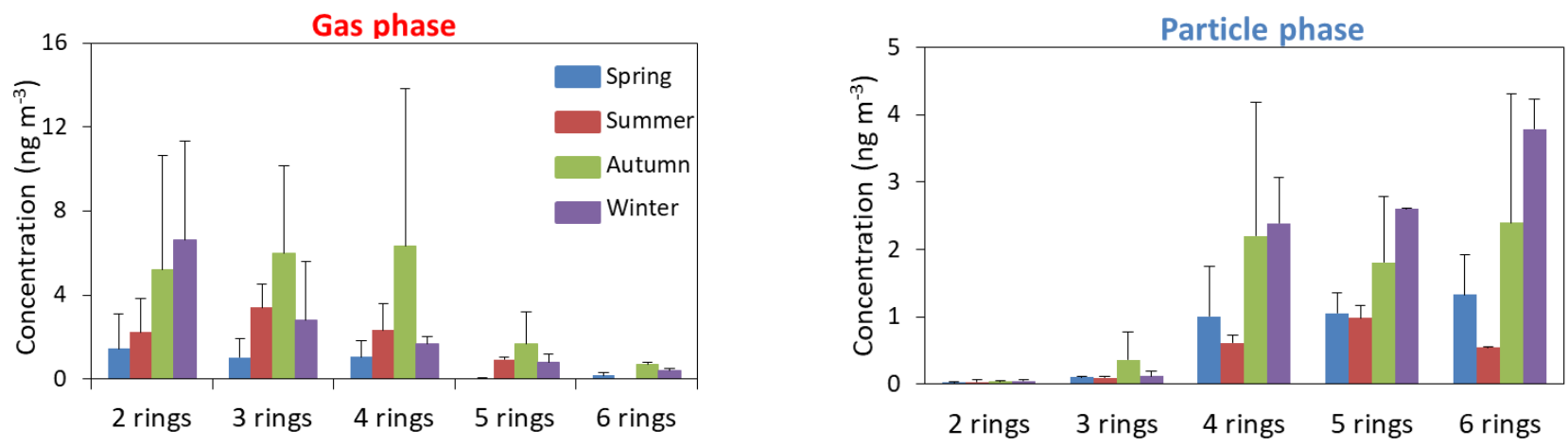

Figure 3. Concentration of PAHs with different numbers of rings in the particle and gas phases for four seasons.

In this study, low molecular weight (LMW) (2-ring and 3-ring) and MMW (4-ring) PAHs contribute dominantly to the gas phase, while the particulate phase is associated with MMW (4-ring) and HMW (5-ring and 6-ring) PAHs. This result shows the same trend as a number of previous studies [34,35]. The concentration of low-ring PAHs $(99 \%$ of 2-ring and 95\% of 3-ring) was found to be higher in the gas phase than in the particulate phase due to their high vapor pressures and low octanol-air partition coefficient. For the 4-ring PAHs, they were found in similar composition in both phases with a little bit more in the gas phase (64\%), while $80 \%$ of HMW (5-ring and 6-ring) PAHs were measured in the particulate phase. Furthermore, the concentration of 2-ring PAHS in the gas phase increased with the decreasing of the temperature. This observation is probably due to the low level of photochemical reactions on 2-ring PAHs with lower temperature. For the concentration of 3-ring and 4-ring PAHs, the gas phase was slightly higher in summer than winter. This trend was the same as that reported by Li et al. (2006) [29], implying that under higher ambient temperature, 3-ring and 4-ring PAHs contaminated at ground surface were evaporated [36,37]. In the particulate phase, the dominance of 4-ring, 5-ring, and 6-ring PAHs was higher in the cold season than in the warm season. The increase in these compounds was influenced by the emission source such as combustion of vehicle automobiles and combustion of domestic heating.

Figure $4 \mathrm{a}, \mathrm{b}$ presents the mean concentrations in the gas and particulate phases for each season for each PAH and illustrates the partitioning described before. It can be noted that the PAHs quantified in autumn present the highest concentrations in many cases, and this observation could be explained by the meteorological conditions which are in favor of a stagnation of pollutants in the Rhine Valley in this season.

The log Kp for each PAH was calculated from Equation (1) for the warm and cold periods (Figure 5). It can be seen that the log Kp increased with the molecular weight of the $\mathrm{PAH}$. This result indicates that the proportion of the PAHs in the particulate phase related to the total concentration is more important in high molecular weight PAHs in comparison to low molecular weight PAHs. The values of $\log \mathrm{Kp}$ varied between -4.13 and -1.49 and are consistent with previous data $[19,38,39]$. It can also be observed that the log Kp is different between cold and warm seasons for high molecular weight PAHs but not for low molecular weight PAH. This observation confirms the influence of meteorological conditions on the partitioning of PAHs in the atmosphere. 

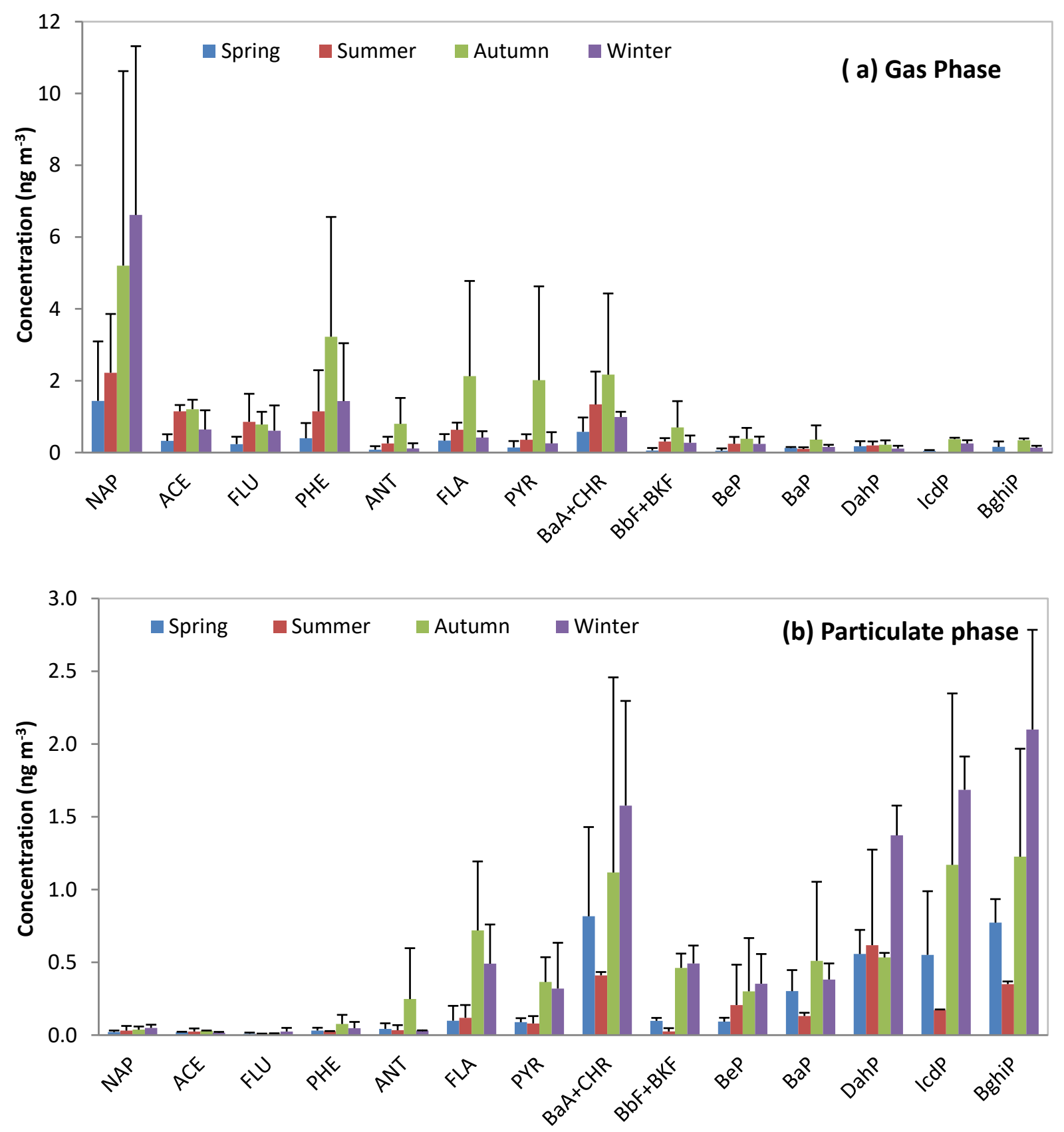

Figure 4. Mean concentration in the gas (a) and particulate phase (b) for each PAH for each season. Error bars represent the standard deviation of the mean compound concentration for all samples in each season. 


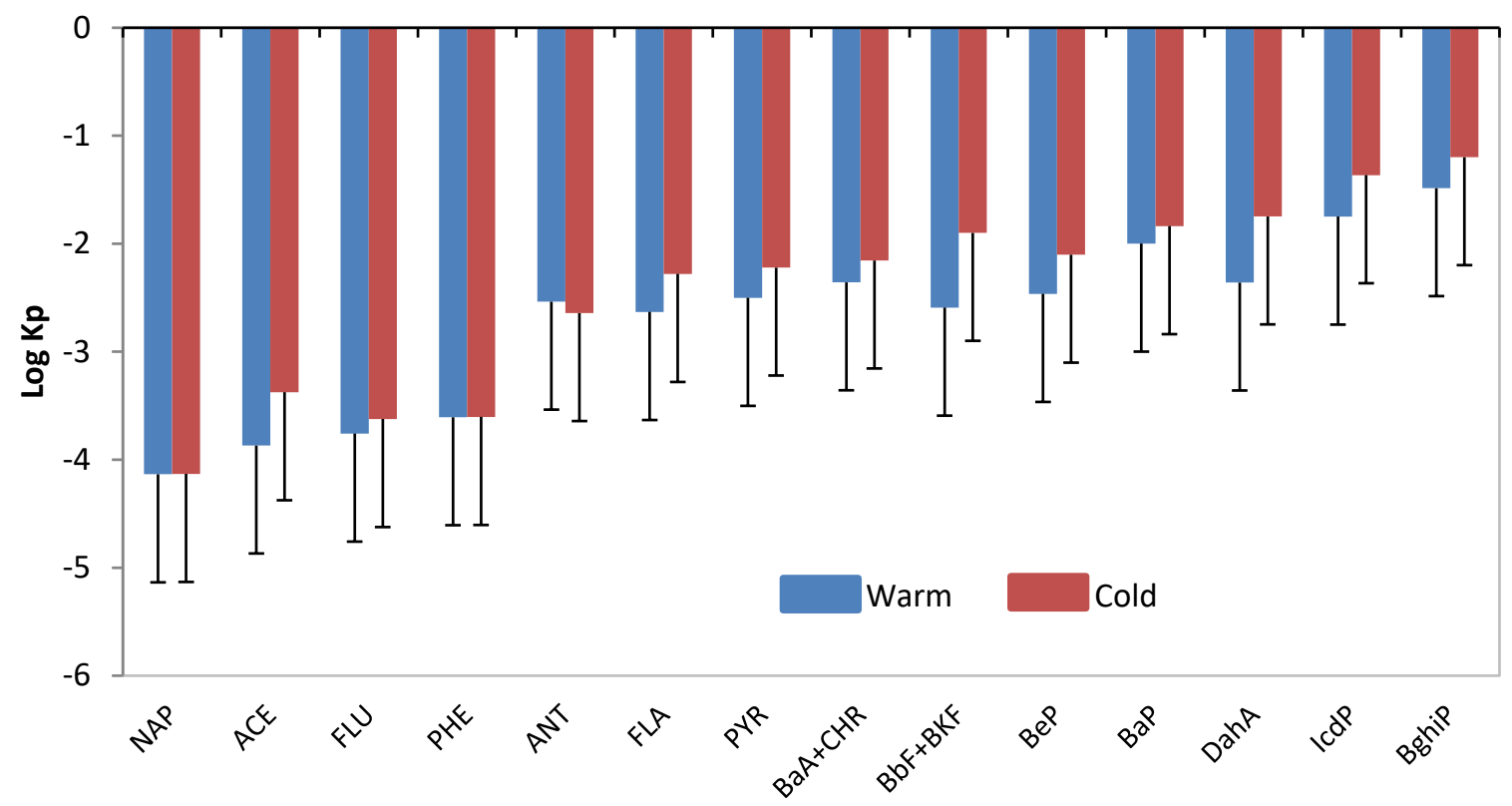

Figure 5. Comparison of the warm and cold seasons with the log Kp of the 16 PAHs. Error bars represent the standard deviation of the mean compound value for all samples in each period.

\subsection{Diagnostic Ratios for Source Identification of PAHs}

The PAH profiles in the atmosphere can be influenced by atmospheric conditions (temperature, solar radiation, wind) and by the sources of PAHs, which can be identified by the concentration of some marker compounds and their diagnostic ratio [40]. The common analytical tool to distinguish petrogenic and pyrogenic sources is to study simultaneously the ratio of the isomers of molecular weight 178 (ANT and PHE) [41]. Low values $(<0.1)$ for this ratio are usually attributed to petrogenic sources, while a ratio greater than 0.1 indicates pyrogenic sources [42], and more precisely, points out that combustion is an important source of PAHs [43,44]. In this study, the range values of ANT/(ANT + PHE) ratio varied between 0.08 and 0.26 , with an average of $0.17 \pm 0.05$, suggesting that a mix of petroleum and combustion sources could be the possible source of atmospheric PAHs in the Strasbourg area.

Some studies also used the ratio between the isomers with molecular weight 202 (FLA and PYR) and 276 (IcdP and BghiP) to discriminate petrogenic sources, petroleum combustion, biomass, and coal combustion $[45,46]$. If the values of FLA/(FLA + PYR) and IcdP /(IcdP + BghiP) are below $<0.4$ and $<0.2$ respectively, this implies a petrogenic source, while a ratio between $0.4-0.5$ and $0.2-0.5$ suggests that the possible source is fossil fuel combustion. A ratio greater than 0.5 is characteristic of wood, grass, or coal combustion [16]. Figure 6 shows the distribution ratios of FLA/(FLA + PYR) versus IcdP/(IcdP + BghiP) for the warm period (squares indicate temperature range $13-24{ }^{\circ} \mathrm{C}$ ) and cold period (dots indicate temperature range $1-12{ }^{\circ} \mathrm{C}$ ), obviously possibly pointing out the different major emission origins of PAHs. The ratio of FLA/(FLA + PYR) ranged from 0.40 to 0.87 with an average of $0.61 \pm 0.19$ for the warm period, and from 0.36 to 0.91 with an average of $0.67 \pm 0.17$ for the cold period. The IcdP/(IcdP + BghiP) was between 0.34 and 0.54 with an average of $0.42 \pm 0.08$ for the warm period, and between 0.23 and 0.62 with an average of $0.45 \pm 0.11$ for the cold period. All of these two ratios indicate that fuel combustion and biomass/coal burning are the possible origins of PAHs in Strasbourg. In France, the main source of PAHs ( $>55 \%$ ) is the residential/tertiary sector and in Alsace, with more than $87 \%$, emissions are due to domestic heating with wood and due to the transport sector by diesel and gasoline combustion $[47,48]$. These data confirmed the results obtained in this work, in which the concentrations of atmospheric PAHs in Strasbourg are mainly the consequence of emissions from combustion of wood, diesel, and gasoline. The distribution of IcdP(IcdP 
+ BghiP) ratios for the warm period (squares) is more present in the fuel combustion zone than in the biomass zone, while the ratio for the cold period is similarly distributed in both zones. This observation is probably due to the increase in wood burning for heating in the cold period.

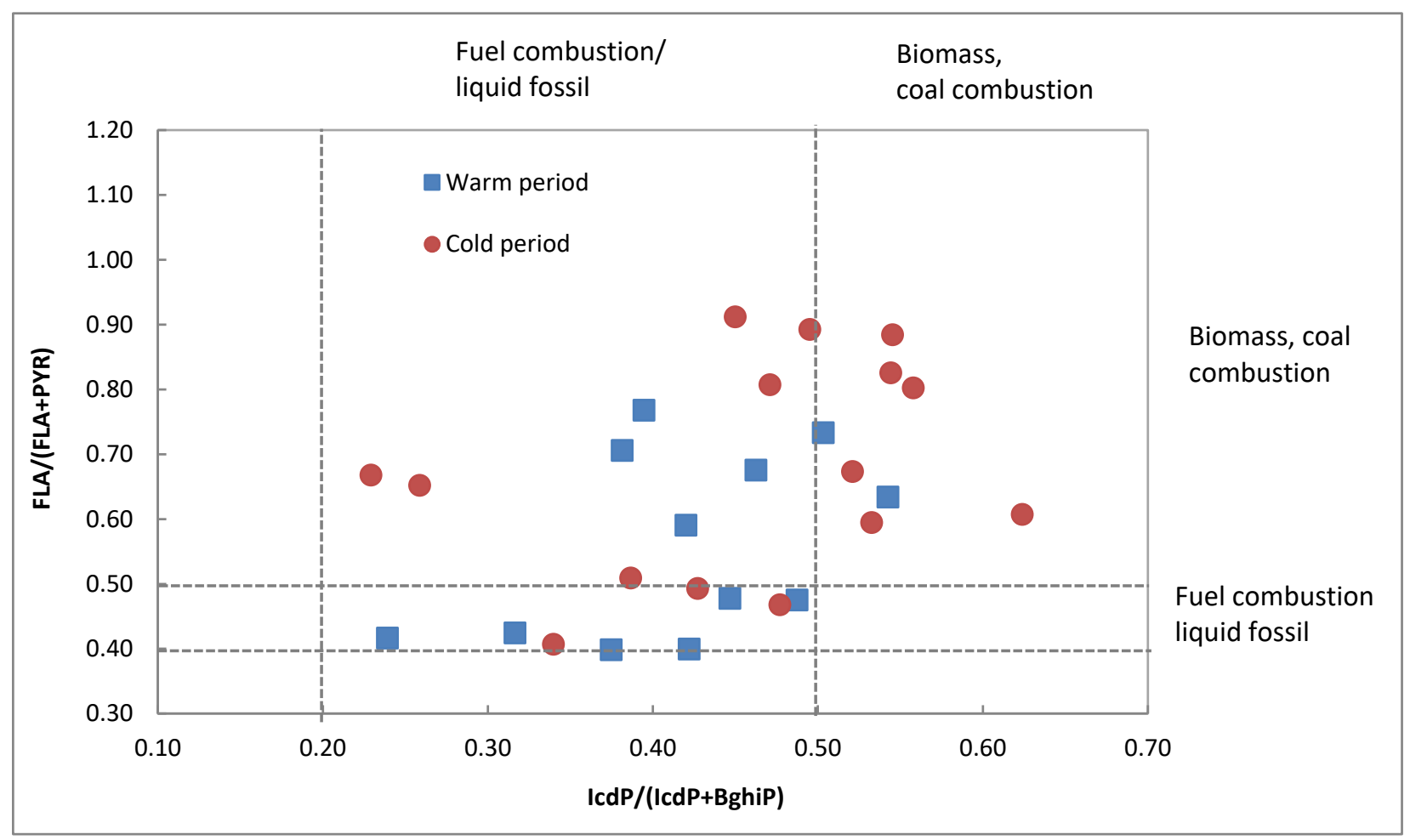

Figure 6. Ratio of FLA/(FLA + PYR) versus IcdP/(IcdP + BhiP) for the warm (16 May-23 October 2018 and 16 April-29 October 2019) and cold (23 October 2018-16 April 2019 and 6 November 2019-17 March 2020) time periods.

Additionally, Table 2 lists the diagnostic ratios of some PAHs such as PHE/(PHE + ANT), FLA(FLA + PYR), BaP/(BaP + CHR), IcdP/(IcdP + BghiP), and BaP/(BaP + BeP), which have been usually used as indicators to distinguish their origins $[37,49,50]$.

Table 2. Comparison among PAH ratios obtained from samples from this study for four seasons and possible emission sources in the Strasbourg area.

\begin{tabular}{|c|c|c|c|c|c|c|}
\hline & \multirow{2}{*}{ Seasons } & \multicolumn{5}{|l|}{ Diagnostic Ratio } \\
\hline & & PHE/(ANT + PHE) & FLA/(FLA + PYR) & $\mathrm{BaP} /(\mathrm{BaP}+\mathrm{CHR})$ & IcdP/(IcdP + BghiP) & $\mathrm{BeP} /(\mathrm{BaP}+\mathrm{BeP})$ \\
\hline \multirow{8}{*}{$\begin{array}{l}\text { This } \\
\text { study }\end{array}$} & SP2018 & $0.77 \pm 0.13$ & $0 . .69 \pm 0.20$ & $0.47 \pm 0.14$ & $0.41 \pm 0.02$ & $0.44 \pm 0.24$ \\
\hline & SP2019 & $0.78 \pm 0.21$ & $0.68 \pm 0.16$ & $0.42 \pm 0.07$ & $0.47 \pm 0.06$ & $0.30 \pm 0.07$ \\
\hline & S2018 & $0.69 \pm 0.21$ & $0.42 \pm 0.13$ & $0.36 \pm 0.17$ & $0.38 \pm 0.11$ & $0.44 \pm 0.30$ \\
\hline & S2019 & $0.87 \pm 0.02$ & $0.45 \pm 0.20$ & $0.39 \pm 0.18$ & $0.24 \pm 0.15$ & $0.55 \pm 0.08$ \\
\hline & A2018 & $0.87 \pm 0.12$ & $0.67 \pm 0.23$ & $0.40 \pm 0.15$ & $0.32 \pm 0.10$ & $0.53 \pm 0.16$ \\
\hline & A2019 & $0.84 \pm 0.11$ & $0.61 \pm 0.17$ & $0.42 \pm 0.16$ & $0.47 \pm 0.04$ & $0.47 \pm 0.11$ \\
\hline & W2018 & $0.80 \pm 0.12$ & $0.82 \pm 0.13$ & $0.48 \pm 0.14$ & $0.51 \pm 0.09$ & $0.33 \pm 0.11$ \\
\hline & W2019 & $0.92 \pm 0.03$ & $0.54 \pm 0.14$ & $0.51 \pm 0.16$ & $0.42 \pm 0.12$ & $0.73 \pm 0.16$ \\
\hline \multirow{3}{*}{$\begin{array}{c}\text { Source } \\
\text { emission }\end{array}$} & Gasoline & $0.77 \pm 0.10^{\mathrm{a}}$ & $0.40^{\mathrm{b}}$ & $0.22-0.55^{\mathrm{d}}$ & $0.32 \pm 0.17^{\mathrm{a}}$ & \multirow{3}{*}{$0.4-0.5^{\mathrm{e}}$} \\
\hline & Diesel & $0.73 \pm 0.18^{\mathrm{a}}$ & $0.43^{c}$ & $0.38-0.64^{\mathrm{e}}$ & $0.37^{\mathrm{g}}$ & \\
\hline & Wood & $0.84 \pm 0.16^{\mathrm{a}}$ & $0.62^{c}$ & $0.43^{\mathrm{f}}$ & $0.42 \pm 0.18^{a}$ & \\
\hline
\end{tabular}

${ }^{a}$ US EPA 1999 [51]; ${ }^{\text {b }}$ Rogge et al. 1993 [52]; ${ }^{\text {c }}$ Manoli et al. 2004 [53]; ${ }^{\mathrm{d}}$ Simcik et al. 1999 [54]; ${ }^{\mathrm{e}}$ Sicre et al. 1987 [55]; ${ }^{\mathrm{f}}$ Li and Kamens 1993 [56]; g Grimmer et al. 1983 [57]. 
In 2018, the ratios of PHE/(PHE + ANT) were $0.77 \pm 0.13,0.69 \pm 0.21,0.87 \pm 0.12$, and $0.80 \pm 0.12$ for spring, summer, autumn, and winter, respectively, and these ratios were similar to the literature and have been reported from emissions by gasoline vehicles $(0.77 \pm 0.10)$, diesel vehicles $(0.73 \pm 0.18)$, and wood combustion $(0.84 \pm 0.16)$. The ratio of $\mathrm{BaA} /(\mathrm{BaA}+\mathrm{Chry})$ is generally used to evaluate the contribution of vehicular emissions.

The values obtained in this study were 0.42 and 0.47 in spring, 0.36 and 0.39 in summer, 0.40 and 0.42 in autumn, and 0.42 and 0.51 in winter. The reported literature values for this ratio were $0.22-0.55,0.38-0.64$, and 0.42 , for gasoline, diesel, and wood respectively. This information confirms the importance of gasoline, diesel, and wood combustion in Strasbourg's atmosphere.

In the summer season, the ratios of FLA/(FLA + PYR) $(0.42-0.45), \mathrm{BaP} /(\mathrm{BaP}+\mathrm{CHR})$ (0.36-0.39), and IcdP/(IcdP + BghiP) (0.24 and 0.38) were lower than those observed in winter. The lower summer values of the ratios are explained by the decreasing of wood combustion in the summer. All the ratios considered have shown that the emission sources of PAHs in the Strasbourg area are not well defined, but there is evidence that emission of PAHs from diesel, gasoline, and wood combustion occurred at the same time.

\section{Conclusions}

In this study, the temporal characteristics of PAHs in the gaseous and particulate phases were studied from May 2018 to March 2020 at an urban site in Strasbourg, in the northeastern region of France. This study provides data on the PAH concentrations and variabilities for a typical large metropolis, with important activities around it, situated in a Rhine Valley. The annual trends of $\Sigma_{16} \mathrm{PAH}$ concentration in both gas and particulate phases with temperature were studied, and it was found for gas phase samples that the mean concentration of $\Sigma_{16}$ PAHs was $11.36 \mathrm{ng} \mathrm{m}^{-3}$, with a maximum of $79 \mathrm{ng} \mathrm{m}^{-3}$ on 12 to 19 November 2019 , with temperature $4.8 \pm 0.91{ }^{\circ} \mathrm{C}$, and a minimum of $0.74 \mathrm{ng} \mathrm{m}^{-3}$ on 29 May to 5 June 2018, with temperature $22.4 \pm 1.46^{\circ} \mathrm{C}$. The PAH concentration in the particulate phase was considerably lower, with a mean value of $5.51 \mathrm{ng} \mathrm{m}^{-3}$, and ranged from 0.29 to $21.73 \mathrm{ng} \mathrm{m}^{-3}$. The seasonal variability of PAH concentrations was observed in accordance with known behavior, with higher values in autumn and winter and lower values in spring and summer. For the gas phase, the maximum concentration was in spring, with a slight decrease in winter with lower temperature, and the minimum concentration was in spring, with slightly higher concentrations in summer with a higher temperature (warm and non-heating season). Moreover, the profiles of relative distribution of PAHs with different numbers of rings for four seasons in Strasbourg were studied, and the results indicate that LMW (2-ring and 3-ring) and MMW (4-ring) PAHs contribute dominantly to the gas phase, while the particulate phase is associated with MMW (4ring) and HMW (5-ring and 6-ring) PAHs. The values of log Kp confirm the influence of meteorological conditions on the partitioning of PAHs in the atmosphere. Finally, a trend may be established using the diagnostics ratios, with fuel combustion and biomass/coal burning being the possible origins of PAHs in Strasbourg. These origins are not defined, but there is evidence that emissions of PAHs from diesel, gasoline, and wood combustion occurred at the same time.

Supplementary Materials: The following are available online at https:/ /www.mdpi.com/2073-443 3/12/3/337/s1, Table S1: MS parameters, LOD, and LOQ for the 16 analyzed PAHs.

Author Contributions: Conceptualization, S.C., O.D. and M.M.; methodology, S.C. and M.M.; validation, S.C.; formal analysis, S.C. and O.D.; writing-original draft preparation, S.C. and O.D.; writingreview and editing. All authors have read and agreed to the published version of the manuscript.

Funding: This research received no external funding. 
Institutional Review Board Statement: Not applicable.

Informed Consent Statement: Not applicable.

Conflicts of Interest: The authors declare no conflict of interest.

\section{References}

1. Baek, S.O.; Field, R.A.; Goldstone, M.E.; Kirk, P.W.; Lester, J.N.; Perry, R. A review of atmospheric polycyclic aromatic hydrocarbons: Sources, fate and behavior. Water Air Soil Pollut. 1991, 60, 279-300. [CrossRef]

2. Pozo, K.; Harner, T.; Shoeib, M.; Urrutia, R.; Barra, R.; Parra, O.; Focardi, S. Passive-Sampler Derived Air Concentrations of Persistent Organic Pollutants on a North-South Transect in Chile. Environ. Sci. Technol. 2004, 38, 6529-6537. [CrossRef]

3. Tasdemir, Y.; Esen, F. Urban air PAHs: Concentrations, temporal changes and gas/particle partitioning at a traffic site in Turkey. Atmos. Res. 2007, 84, 1-12. [CrossRef]

4. Halsall, C.; Sweetman, A.J.; Barrie, L.; Jones, K.C. Modeling the behavior of PAHs during atmospheric transport from the UK to the Arctic. Atmos. Environ. 2001, 35, 255-267. [CrossRef]

5. Ma, W.-L.; Liu, L.-Y.; Jia, H.-L.; Yang, M.; Li, Y.-F. PAHs in Chinese atmosphere Part I: Concentration, source and temperature dependence. Atmos. Environ. 2018, 173, 330-337. [CrossRef]

6. Ma, W.-L.; Zhu, F.-J.; Liu, L.-Y.; Jia, H.-L.; Yang, M.; Li, Y.-F. PAHs in Chinese atmosphere Part II: Health risk assessment. Ecotoxicol. Environ. Saf. 2020, 200, 110774. [CrossRef]

7. Kim, K.-H.; Jahan, S.A.; Kabir, E.; Brown, R.J. A review of airborne polycyclic aromatic hydrocarbons (PAHs) and their human health effects. Environ. Int. 2013, 60, 71-80. [CrossRef] [PubMed]

8. Balcioğlu, E.B. Potential effects of polycyclic aromatic hydrocarbons (PAHs) in marine foods on human health: A critical review. Toxin Rev. 2016, 35, 98-105. [CrossRef]

9. Li, X.; Yang, Y.; Xu, X.; Xu, C.; Hong, J. Air pollution from polycyclic aromatic hydrocarbons generated by human activities and their health effects in China. J. Clean. Prod. 2016, 112, 1360-1367. [CrossRef]

10. Drwal, E.; Rak, A.; Gregoraszczuk, E.L. Review: Polycyclic aromatic hydrocarbons (PAHs)—Action on placental function and health risks in future life of newborns. Toxicology 2019, 411, 133-142. [CrossRef]

11. Jensen, J.; Sverdrup, L.E. Polycyclic aromatic hydrocarbon ecotoxicity data for developing soil quality criteria. Rev. Environ. Contam. Toxicol. 2003, 179, 73-97. [CrossRef]

12. Sverdrup, L.E.; Nielsen, T.; Krogh, P.H. Soil Ecotoxicity of Polycyclic Aromatic Hydrocarbons in Relation to Soil Sorption, Lipophilicity, and Water Solubility. Environ. Sci. Technol. 2002, 36, 2429-2435. [CrossRef] [PubMed]

13. Morville, S.; Delhomme, O.; Millet, M. Seasonal and diurnal variations of atmospheric PAH concentrations between rural, suburban and urban areas. Atmos. Pollut. Res. 2011, 2, 366-373. [CrossRef]

14. Delhomme, O.; Millet, M. Characterization of particulate polycyclic aromatic hydrocarbons in the east of France urban areas. Environ. Sci. Pollut. Res. 2011, 19, 1791-1799. [CrossRef]

15. Albuquerque, M.; Coutinho, M.; Borrego, C. Long-term monitoring and seasonal analysis of polycyclic aromatic hydrocarbons (PAHs) measured over a decade in the ambient air of Porto, Portugal. Sci. Total. Environ. 2016, 543, 439-448. [CrossRef]

16. Liu, B.; Xue, Z.; Zhu, X.; Jia, C. Long-term trends (1990-2014), health risks, and sources of atmospheric polycyclic aromatic hydrocarbons (PAHs) in the U.S. Environ. Pollut. 2017, 220, 1171-1179. [CrossRef] [PubMed]

17. Zhang, J.; Wang, P.; Li, J.; Mendola, P.; Sherman, S.; Ying, Q. Estimating population exposure to ambient polycyclic aromatic hydrocarbon in the United States-Part II: Source apportionment and cancer risk assessment. Environ. Int. 2016, 97, 163-170. [CrossRef]

18. Zhang, J.; Li, J.; Wang, P.; Chen, G.; Mendola, P.; Sherman, S.; Ying, Q. Estimating population exposure to ambient polycyclic aromatic hydrocarbon in the United States_Part I: Model development and evaluation. Environ. Int. 2017, 99, 263-274. [CrossRef]

19. Ma, W.-L.; Zhu, F.-J.; Liu, L.-Y.; Jia, H.-L.; Yang, M.; Li, Y.-F. PAHs in Chinese atmosphere: Gas/particle partitioning. Sci. Total. Environ. 2019, 693, 133623. [CrossRef] [PubMed]

20. Nielsen, T.; Jørgensen, H.E.; Larsen, J.C.; Poulsen, M. City air pollution of polycyclic aromatic hydrocarbons and other mutagens: Occurrence, sources and health effects. Sci. Total. Environ. 1996, 189-190, 41-49. [CrossRef]

21. Prevedouros, K.; MacLeod, M.; Jones, K.C.; Sweetman, A.J. Modelling the fate of persistent organic pollutants in Europe: Parameterisation of a gridded distribution model. Environ. Pollut. 2004, 128, 251-261. [CrossRef] [PubMed]

22. Sienra, M.D.R.; Rosazza, N.G.; Préndez, M. Polycyclic aromatic hydrocarbons and their molecular diagnostic ratios in urban atmospheric respirable particulate matter. Atmos. Res. 2005, 75, 267-281. [CrossRef]

23. Al-Alam, J.; Lévy, M.; Ba, H.; Pham-Huu, C.; Millet, M. Passive air samplers based on ceramic adsorbent for monitoring of pesticides, polycyclic aromatic hydrocarbons and polychlorinated biphenyls in outdoor air. Environ. Technol. Innov. 2020, 20, 101094. [CrossRef]

24. Levy, M.; Alam, J.-; Delhomme, O.; Millet, M. An integrated extraction method coupling pressurized solvent extraction, solid phase extraction and solid-phase micro extraction for the quantification of selected organic pollutants in air by gas and liquid chromatography coupled to tandem mass spectrometry. Microchem. J. 2020, 157, 104889. [CrossRef]

25. Yamasaki, H.; Kuwata, K.; Miyamoto, H. Effects of ambient temperature on aspects of airborne polycyclic aromatic hydrocarbons. Environ. Sci. Technol. 1982, 16, 189-194. [CrossRef] 
26. Albinet, A.; Leoz-Garziandia, E.; Budzinski, H.; ViIlenave, E. Polycyclic aromatic hydrocarbons (PAHs), nitrated PAHs and oxygenated PAHs in ambient air of the Marseilles area (South of France): Concentrations and sources. Sci. Total. Environ. 2007, 384, 280-292. [CrossRef]

27. Tomaz, S.; Shahpoury, P.; Jaffrezo, J.-L.; Lammel, G.; Perraudin, E.; Villenave, E.; Albinet, A. One-year study of polycyclic aromatic compounds at an urban site in Grenoble (France): Seasonal variations, gas/particle partitioning and cancer risk estimation. Sci. Total. Environ. 2016, 565, 1071-1083. [CrossRef]

28. Tian, F.; Chen, J.; Qiao, X.; Wang, Z.; Yang, P.; Wang, D.; Ge, L. Sources and seasonal variation of atmospheric polycyclic aromatic hydrocarbons in Dalian, China: Factor analysis with non-negative constraints combined with local source fingerprints. Atmos. Environ. 2009, 43, 2747-2753. [CrossRef]

29. Li, J.; Zhang, G.; Li, X.D.; Qi, S.H.; Liu, G.Q.; Peng, X.Z. Source seasonality of polycyclic aromatic hydrocarbons (PAHs) in a subtropical city, Guangzhou, South China. Sci. Total. Environ. 2006, 355, 145-155. [CrossRef]

30. Sanderson, E. Comparison of particulate polycyclic aromatic hydrocarbon profiles in different regions of Canada. Atmos. Environ. 2004, 38, 3417-3429. [CrossRef]

31. Tsapakis, M.; Stephanou, E.G. Occurrence of gaseous and particulate polycyclic aromatic hydrocarbons in the urban atmosphere: Study of sources and ambient temperature effect on the gas/particle concentration and distribution. Environ. Pollut. 2005, 133, 147-156. [CrossRef]

32. Esen, F.; Tasdemir, Y.; Vardar, N. Atmospheric concentrations of PAHs, their possible sources and gas-to-particle partitioning at a residential site of Bursa, Turkey. Atmos. Res. 2008, 88, 243-255. [CrossRef]

33. Wang, D.; Yang, M.; Jia, H.; Zhou, L.; Li, Y. Seasonal variation of polycyclic aromatic hydrocarbons in soil and air of Dalian areas, China: An assessment of soil-air exchange. J. Environ. Monit. 2008, 10, 1076-1083. [CrossRef]

34. Bi, X.; Sheng, G.; Peng, P.; Chen, Y.; Zhang, Z.; Fu, J. Distribution of particulate- and vapor-phase n-alkanes and polycyclic aromatic hydrocarbons in urban atmosphere of Guangzhou, China. Atmos. Environ. 2003, 37, 289-298. [CrossRef]

35. Park, S.S.; Kim, Y.J.; Kang, C.H. Atmospheric polycyclic aromatic hydrocarbons in Seoul, Korea. Atmos. Environ. 2002, 36, 2917-2924. [CrossRef]

36. Dimashki, M.; Lim, L.H.; Harrison, R.M.; Harrad, S. Temporal Trends, Temperature Dependence, and Relative Reactivity of Atmospheric Polycyclic Aromatic Hydrocarbons. Environ. Sci. Technol. 2001, 35, 2264-2267. [CrossRef]

37. Odabasi, M.; Vardar, N.; Sofuoglu, A.; Tasdemir, Y.; Holsen, T.M. Polycyclic aromatic hydrocarbons (PAHs) in Chicago air. Sci. Total. Environ. 1999, 227, 57-67. [CrossRef]

38. Lohmann, R.; Northcott, G.L.; Jones, K.C. Assessing the Contribution of Diffuse Domestic Burning as a Source of PCDD/Fs, PCBs, and PAHs to the U.K. Atmosphere. Environ. Sci. Technol. 2000, 34, 2892-2899. [CrossRef]

39. Verma, P.K.; Sah, D.; Kumari, K.M.; Lakhani, A. Atmospheric concentrations and gas-particle partitioning of polycyclic aromatic hydrocarbons (PAHs) and nitro-PAHs at Indo-Gangetic sites. Environ. Sci. Process. Impacts 2017, 19, 1051-1060. [CrossRef]

40. Tobiszewski, M.; Namieśnik, J. PAH diagnostic ratios for the identification of pollution emission sources. Environ. Pollut. 2012, 162, 110-119. [CrossRef]

41. Katsoyiannis, A.; Sweetman, A.J.; Jones, K.C. PAH Molecular Diagnostic Ratios Applied to Atmospheric Sources: A Critical Evaluation Using Two Decades of Source Inventory and Air Concentration Data from the UK. Environ. Sci. Technol. 2011, 45, 8897-8906. [CrossRef]

42. Pies, C.; Hoffmann, B.; Petrowsky, J.; Yang, Y.; Ternes, T.A.; Hofmann, T. Characterization and source identification of polycyclic aromatic hydrocarbons (PAHs) in river bank soils. Chemosphere 2008, 72, 1594-1601. [CrossRef]

43. Blasco, M.; Domeño, C.; Nerín, C. Use of Lichens as Pollution Biomonitors in Remote Areas: Comparison of PAHs Extracted from Lichens and Atmospheric Particles Sampled in and Around the Somport Tunnel (Pyrenees). Environ. Sci. Technol. 2006, 40, 6384-6391. [CrossRef]

44. Zhou, J.; Wang, T.; Huang, Y.; Mao, T.; Zhong, N. Size distribution of polycyclic aromatic hydrocarbons in urban and suburban sites of Beijing, China. Chemosphere 2005, 61, 792-799. [CrossRef]

45. De La Torre-Roche, R.J.; Lee, W.-Y.; Campos-Díaz, S.I. Soil-borne polycyclic aromatic hydrocarbons in El Paso, Texas: Analysis of a potential problem in the United States/Mexico border region. J. Hazard. Mater. 2009, 163, 946-958. [CrossRef]

46. Yunker, M.B.; Macdonald, R.W.; Vingarzan, R.; Mitchell, R.H.; Goyette, D.; Sylvestre, S. PAHs in the Fraser River basin: A critical appraisal of PAH ratios as indicators of PAH source and composition. Org. Geochem. 2002, 33, 489-515. [CrossRef]

47. CITEPA. Le Rapport de Référence sur les Emissions de Gaz à Effet de Serre et de Polluants Atmosphériques en France. 2019. Available online: https://www.citepa.org/fr/activites/inventaires-des-emissions/secten (accessed on 5 March 2021).

48. ASPA: Association for the Monitoring and Study of Atmospheric Pollution in Alsace. Available online: http://www.atmo-alsace. net/medias/produits/Bilan_de_la_qualite_de_2.pdf (accessed on 5 March 2021).

49. Akyüz, M.; Çabuk, H. Gas-particle partitioning and seasonal variation of polycyclic aromatic hydrocarbons in the atmosphere of Zonguldak, Turkey. Sci. Total. Environ. 2010, 408, 5550-5558. [CrossRef]

50. Zhao, J.; Zhang, F.; Xu, L.; Chen, J.; Xu, Y. Spatial and temporal distribution of polycyclic aromatic hydrocarbons (PAHs) in the atmosphere of Xiamen, China. Sci. Total. Environ. 2011, 409, 5318-5327. [CrossRef] [PubMed]

51. U.S. EPA. 1999 National Emissions Inventory; US EPA: Washington, DC, USA, 2003. Available online: ftp://ftp.epa.gov/ EmisInventory / finalnei99ver3/haps / (accessed on 5 March 2021). 
52. Rogge, W.F.; Hildemann, L.M.; Mazurek, M.A.; Cass, G.R.; Simoneit, B.R.T. Sources of fine organic aerosol. 2. Non-catalyst and catalyst-equipped automobiles and heavy duty diesel trucks. Environ. Sci. Technol. 1993, 27, 636-651. [CrossRef]

53. Manoli, E.; Kouras, A.; Samara, C. Profile analysis of ambient and source emitted particle-bound polycyclic aromatic hydrocarbons from three sites in northern Greece. Chemosphere 2004, 56, 867-878. [CrossRef] [PubMed]

54. Simcik, M.F.; Eisenreich, S.J.; Lioy, P.J. Source apportionment and source/sink relationships of PAHs in the coastal atmosphere of Chicago and Lake Michigan. Atmos. Environ. 1999, 33, 5071-5079. [CrossRef]

55. Sicre, M.; Marty, J.; Saliot, A.; Aparicio, X.; Grimalt, J.; Albaiges, J. Aliphatic and aromatic hydrocarbons in different sized aerosols over the Mediterranean Sea: Occurrence and origin. Atmos. Environ. 1987, 21, 2247-2259. [CrossRef]

56. Li, C.K.; Kamens, R.M. The use of polycyclic aromatic hydrocarbons as source signatures in receptor modeling. Atmos. Environ. Part A Gen. Top. 1993, 27, 523-532. [CrossRef]

57. Grimmer, G.; Jacob, J.; Naujack, K.W. Profile of the polycyclic aromatic compounds from crude oils- Part3: Inventory by GC, GC6MS PAH in environmental Materials. Fres. Z. Anal. Chem. 1983, 316, 29-36. [CrossRef] 